Jurnal

Kardiologi Indonesia

J Kardiol Indones. 2014;35:70-9

ISSN 0I26/3773

Clinical Research

\title{
Preoperative and predischarge predictors for persistent pulmonary hypertension after mitral valve surgery in patients with chronic organic mitral regurgitation
}

\author{
Rina Ariani, Indriwanto Sakidjan, Budhi Setianto
}

Departemen Kardiologi dan Kedokteran Vaskular Fakultas Kedokteran Universitas Indonesia

Pusat Jantung Nasional Harapan Kita Jakarta
Objectives. This study sought to evaluate the prevalence of pulmonary hypertension after mitral valve surgery ini patients with chronic organic mitral regurgitation and to determine preoperative and predischarge predictors for persistent pulmonary hypertension after surgery

Methods. This is a cohort retrospective study involving subjects with chronic organic mitral regurgitation with preoperative systolic PA pressure $\geq 50 \mathrm{mmHg}$ undergoing surgery. Demographic and echocardiography datas were collected prior to surgery, predischarge, and follow up datas were evaluated after minimal 6 months duration. Subjects were then devided into groups based on existence of persistent pulmonary hypertension after follow up. Bivariate and multivariate analysis was done to determine contributing factors.

Results. There were 92 subjects with dominant mitral regurgitation included in this study with median age 40 (range 17-68) years with slight female predominance (55\%). Persistent pulmonary hypertension was observed in 23 subjects (25\%) predischarge and in 20 subjects (20.7\%) after mean follow up of I I \pm 5.5 months. Bivariate analysis revealed preoperative TAPSE, underlying etiology, severity of pulmonary hypertension preoperatively, postoperative atrial fibrilation, mean mitral valve gradient predischarge, and the presence of residual pulmonary hypertension predischarge were related with persistent pulmonary hypertension. From multivariate analysis, post operative atrial fibrillation [OR 7.3 (Cl 95\% I.64-33.33, $\mathrm{p}=0.09)$ ], mean mitral valve gradient predischarge [OR I.67 (Cl 95\% I ,3-2.7, $\mathrm{p}=0.038)$ ], and preoperative TAPSE [OR 0. I 43 ( $\mathrm{Cl} 95 \%$ 0.03-0.70, $\mathrm{p}=0.0 \mathrm{I}$ )] were independent predictors for persistent pulmonary hypertension after mitral valve surgery.

Conclusion. Persistent pulmonary hypertension was observed in $20.7 \%$ subjects after mitral valve surgery. Preoperative TAPSE, post operative atrial fibrillation, and predischarge mean mitral valve gradient were independent predictors.

(J Kardiol Indones. 20 I4;35:70-9)

Keywords: Persistent pulmonary hypertension, mitral regurgitation, atrial fibrillation, mean mitral valve gradient, TAPSE 


\title{
Prediktor pra dan segera setelah operasi terhadap hipertensi pulmoner persistenpasca operasi koreksi regurgitasi mitral organik kronik
}

\author{
Rina Ariani, Indriwanto Sakidjan, Budhi Setianto
}

\begin{abstract}
Tujuan. Studi ini bertujuan untuk mengetahui prevalensi hipertensi pulmoner persisten pasca pembedahan katup mitral pada regurgitasi mitral organik kronik dan mengetahui prediktor pra dan segera setelah operasi terhadap terjadinya hipertensi pulmoner persisten pasca operasi.

Metode. Penelitian ini merupakan studi kohort retrospektif yang dilakukan pada pasien dominan regurgitasi mitral kronik akibat kelainan organik dengan tekanan sistolik arteri pulmoner pra operatif $\geq 50 \mathrm{mmHg}$. Dilakukan pengambilan data rekam medis dan ekokardiografi pasien sebelum operasi, segera setelah operasi (predischarge), dan saat follow up minimal 6 bulan. Dilakukan pengelompokan berdasarkan ada/tidaknya hipertensi pulmoner persisten saat follow up dan dilakukan analisa bivariat dan multivariat untuk menilai faktor-faktor yang berhubungan.

Hasil. Didapatkan 92 subjek dengan kelainan dominan regurgitasi mitral dengan nilai median usia 40 tahun (rentang 17 - 68 tahun) dengan dominansi perempuan (55\%). Hipertensi pulmoner persisten didapatkan pada 23 subjek (25\%) segera pasca operasi dan pada 20 subjek (20.7\%) saat follow up lanjutan dengan rerata waktu follow up $11 \pm 5.5$ bulan. Dari analisis bivariat didapatkan nilai TAPSE pra operatif, etiologi, beratnya derajat hipertensi pulmoner pra operatif, irama atrial fibrilasi pasca operasi, nilai rerata gradien transmitral segera pasca operasi, dan ada tidaknya residual hipertensi pulmoner segera pasca operasi merupakan faktor-faktor yang berhubungan dengan hipertensi pulmoner persisten. Dari analisis multivariat didapatkan irama atrial fibrilasi pasca operasi [OR 7.3 (IK 95\% 1.64-33.33, p=0.09)], nilai rerata gradien transmitral segera pasca operasi [OR 1.67 (IK 95\% 1,3-2.7, p=0.038)], dan nilai TAPSE praoperatif [OR 0.143 (IK 95\% 0.03-0.70, p=0.017)] merupakan prediktor independen terhadap hipertensi pumoner persisten pasca operasi koreksi katup mitral.

Kesimpulan Hipertensi pulmoner pasca operasi koreksi katup mitral timbul pada $20.7 \%$ kasus dengan nilai TAPSE pra operatif, irama atrial fibrilasi segera pasca operasi, dan nilai rerata gradien transmitral segera pasca operasi, merupakan prediktor independen terhadap timbulnya persistensi hipertensi.
\end{abstract}

(J Kardiol Indones. 2014;35:70-9)

Kata kunci : Hipertensi pulmoner resisten, regurgitasi mitral, atrial fibrilasi, TAPSE, rerata gradien transmitral

\author{
Alamat Korespondensi \\ Dr Rina Ariani, SpJP. Departemen Kardiologi dan Kedokteran \\ Vaskular Fakultas Kedokteran Universitas Indonesia \\ Pusat Jantung Nasional Harapan Kita Jakarta. E-mail: buete2703@ \\ yahoo.com
}

\section{Pendahuluan}

Regurgitasi katup mitral merupakan penyakit jantung katup dengan prevalensi yang paling banyak setelah stenosis aorta. ${ }^{1}$. Studi epidemiologis yang dilakukan oleh Nkomo dkk pada tahun 2006 didapatkan bahwa 
prevalensi penyakit jantung katup pada populasi umum adalah $2,5 \%$, dengan $68 \%$ diantaranya adalah regurgitasi mitral. ${ }^{2}$

Regurgitasi mitral merupakan masalah mekanikal yang dapat dikoreksi secara mekanikal dengan mengembalikan fungsi katup sehingga menghilangkan kondisi volume overload dan konsekuensinya. Pertimbangan untuk dilakukannya tindakan korektif bergantung pada derajat severitas regurgitasi, telah timbul gejala atau masih asimptomatik, fungsi dan dimensi ventrikel, sekuele yang sudah terjadi seperti fibrilasi atrium, hipertensi pulmonerdan risiko terjadi kematian mendadak. ${ }^{1.3}$

Hipertensi pulmoner didefinisikan sebagai peningkatan tekanan rerata arteri pulmoner saat istirahat $\geq 25 \mathrm{mmHg}$ yang menyebabkan meningkatnya usaha ventrikel kanan untuk memompakan darah ke sistem paru, dan bermanifestasi sebagai sesak napas, menurunnya kapasitas olahraga, fatigue, gagal jantung bahkan kematian. ${ }^{4}$ Timbulnya hipertensi pulmoner pada pasien dengan disfungsi katup menunjukkan stadium lanjut dari penyakit tersebut.Secara patologi, hipertensi pulmoner akibat sekunder dari jantung kiri ditandai dengan pembesaran dan penebalan vena pulmoner, dilatasi kapiler pulmoner, edema intersisial, perdarahan alveolar, serta pembesaran pembuluh limfe. Arteri pulmoner distal mungkin mengalami hipertrofi medial dan fibrosis intima. ${ }^{5}$

Pada sebagian besar hipertensi pulmoner akibat kelainan jantung kiri, termasuk kelainan katup, tekanan arteri pulmoner akan turun dengan menurunnya tekanan pengisian atrium kiri pasca operasi. Namun pada berbagai keadaan, hipertensi pulmoner ini dapat menetap pasca operasi. Vasokonstriksi yang timbul reaktif biasanya mengalami penurunan segera pasca operasi, namun hipertrofi medial atau fibrosis intimal yang terjadi mungkin mengalami perbaikan perlahan atau bahkan tidak mengalami perubahan. ${ }^{6,7}$

Sampai saat ini faktor-faktor yang menyebabkan hipertensi pulmoner pasif berubah menjadi hipertensi pulmoner reaktif masih sulit dipahami. Mekanisme patofisiologis yang diusulkan berupa timbulnya refleks vasokonstriktif reseptor regang yang berlokasi di atrium kiri dan vena pulmoner, serta adanya disfungsi endotel arteri pulmoner yang menyebabkan timbulnya vasokonstriksi dan proliferasi dinding pembuluh darah. ${ }^{5}$ Diduga pada kondisi ini terjadi ketidakseimbangan antara produksi lokal Nitric oxide (NO) dan endotelin-1 (ET-1) oleh endotel yang telah rusak. Dalam sebuah studi dengan menggunakan antagonis NO, terjadi vasokonstriksi pulmoner dan berlanjut pada menigkatnya tekanan arteri pulmoner. Seperti juga NO, ET-1 juga diproduksi oleh endotel, namun mempunyai efek yang berbeda, yaitu merangsang vasokostriksi, menstimulasi pertumbuhan sel otot polos dan kolagen. Pada kondisi dimana terjadi penurunan produksi NO, efek biologis ET-1 akan menjadi dominan, dan akan menyebabkan peningkatan tonus vaskular, dan peningkatan tekanan pulmoner pada kondisi dengan tekanan vena pulmoner yang meningkat dalam situasi kronik. ${ }^{8-10}$

Studi ini bertujuan untuk mengetahui prevalensi hipertensi pulmoner persisten pasca operasi katup mitral organik dengan waktu pengamatan minimal 6 bulan pasca operasi, dan mengetahui faktor-faktor yang berhubungan dengan terjadinya hipertensi pulmoner persisten pasca operasi miral regurgitasi organik dengan waktu pengamatan minimal 6 bulan pasca operasi.

\section{Metodologi Penelitian}

Penelitian ini merupakan studi kohort retrospektifyang dilakukan di Departemen Kardiologi dan Kedokteran Vaskular Fakultas Kedokteran Universitas Indonesia/ Pusat Jantung Nasional Harapan Kita Jakarta, mulai November 2011 s/d April 2012. Subjek penelitian adalah pasien dengan dominan regurgitasi mitral organik kronik dengan hipertensi pulmoner berat (didefinisikan sebagai tekanan tekanan sistolik arteri pulmoner $\geq 50 \mathrm{mmHg}$ ) yang menjalani operasi baik repair ataupun replacement katup mitral sejak januari 2007 s/d juli 2011 di Pusat Jantung Nasional Harapan Kita Jakarta. Kriteria inklusi adalahpasien dengan kelainan dominan regurgitasi mitral organik kronik yang akan menjalani operasi repairl replacement katup mitral dengan tekanan sistolik arteri pulmoner $\geq 50 \mathrm{mmHg}$ berdasarkan gradien regurgitasi trikuspid ditambah estimasi tekanan atrium kanan yang didapat dari data ekokardiografi.Kriteria eksklusi antara lain: pasien dengan penyakit jantung koroner atau kelainan katup aorta bermakna, pasien dengan penyakit komorbid yang dapat menyebabkan timbulnya hipertensi pulmoner (hipertensi, penyakit hati kronis, penyakit tiroid, PPOK atau penyakit paru kronik lainnya, penyakit jantung bawaan), dan pasien yang dalam evaluasi segera atau saat follow up didapatkan disfungsi katup mekanik/ bioprothese bermakna atau didapatkan residual regurgitasi mitral lebih dari derajat ringan.

Data diambil dari rekaman medis pasien dan/ 
atau arsip divisi noninvasif Pusat Jantung Nasional RS Harapan Kita Jakarta. Pengambilan sampel diambil dengan metode consecutive sampling. Dilakukan pengambilan data dasar pada pasien dengan kelainan dominan regurgitasi mitral organik dengan hipertensi pulmoner yang akan menjalani operasi baik repairl replacement, termasuk data ekokardiografi.Dilakukan pengambilan data ulang ekokardiografi kembali segera pasca operasi (jangka waktu 1 hari setelah operasi s/d sebelum pasien rawat jalan)dan dalam follow up minimal 6 bulan pasca operasi (maksimal 24 bulan).Hipertensi pulmoner persisten didefinisikan sebagai hipertensi pulmoner yang masih timbul pasca operasi saat follow up.Uji Kolmogorov-smirnovdilakukan untuk melihat normalitas distribusi data.Uji kemaknaan menggunakan independent-T test/Mann-Whitney test untuk data numerik, dan uji chi-square/ Fisher test untuk data kategorikal. Faktor dengan uji kemaknaan $<0.25$ pada analisis bivariat atau secara klinis dianggap bermakna dan penting akan dimasukkan dalam analisis multivariat. Regresi logistik dengan metode backward stepwisedigunakan untuk menilai prediktor, dengan batas kemaknaan $\mathrm{p}<0.05$. Analisa statistik menggunakan SPSS versi 17.0.

\section{Hasil Penelitian}

Selama waktu penelitian, didapatkan 139 subjek dengan regurgitasi mitral organik kronik dan hipertensi pulmoner berat selama periode Januari 2007 sampai dengan Juli 2011. 23 subjek masuk kriteria eksklusi oleh karena komorbiditi dan disfungsi katup yang

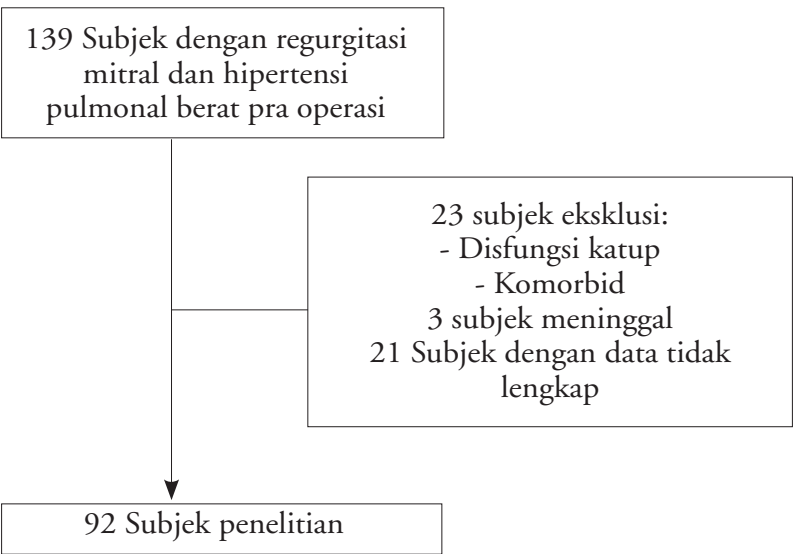

Gambar 1. Alur pemilihan subjek penelitian

Tabel 1. Karakteristik dasar subjek penelitian ( $\mathrm{N}=92)$

\begin{tabular}{|c|c|c|c|c|}
\hline No & Karakteristik & Rerata (SB) & Median (min-max) & N (\%) \\
\hline 1 & Usia (tahun) & & $40(17-68)$ & \\
\hline 2 & Jenis Kelamin (Perempuan) & & & $51(55.4)$ \\
\hline \multirow[t]{4}{*}{3} & Kelas fungsional & & & \\
\hline & a. NYHA FC N-I & & & $20(21.7)$ \\
\hline & b. NYHA FC II-III & & & $65(70.7)$ \\
\hline & c. NYHA FC IV & & & $7(7.6)$ \\
\hline \multirow[t]{3}{*}{4} & Diagnosis & & & \\
\hline & a. Regurgitasi mitral & & & $70(76.1)$ \\
\hline & b. Regurgitasi + stenosis mitral & & & $22(23.9)$ \\
\hline \multirow[t]{4}{*}{5} & Etiologi & & & \\
\hline & a. Rematik & & & $43(46.7)$ \\
\hline & b. Degeneratif & & & $42(45.7)$ \\
\hline & c. Endokarditis infektif & & & $7(7.6)$ \\
\hline 6 & Irama fibrilasi atrium & & & $53(57.6)$ \\
\hline \multirow[t]{8}{*}{7} & Parameter ekokardiografi pra operasi & & & \\
\hline & a. $\operatorname{EDD}(\mathrm{mm})$ & $60.8(7.3)$ & & \\
\hline & b. ESD (mm) & & $39(26-73)$ & \\
\hline & c. Fraksi ejeksi (\%) & $62.5(9.8)$ & & \\
\hline & d. Dimensi atrium kiri $(\mathrm{mm})$ & $57(11.4)$ & & \\
\hline & e. TAPSE $(\mathrm{cm})$ & & $1.9(1.0-3.3)$ & \\
\hline & f. Tekanan sistolik AP (mmHg) & & $65(50-115)$ & \\
\hline & g. Regurgitasi trikuspid bermakna & & & $80(86.9)$ \\
\hline
\end{tabular}

NYHA FC = New York Heart Association functional class, $\mathrm{EDD}=$ end diastolic diameter, $\mathrm{ESD}=$ end systolic diameter, $\mathrm{TAPSE}=$ tricuspid annular plane systolic excursion 
bermakna pasca operasi; 3 pasien meninggal, baik perioperatif atau sebelum periode follow up, dan 21 subjek tidak dapat dilakukan analisa oleh karena data rekam medis yang tidak lengkap, atau tidak dapat dilakukan follow up. Didapatkan 92 subjek penelitian yang akan dilakukan analisa statistik selanjutnya

Nilai median usia subjek penelitian adalah 40 tahun (rentang $17 \mathrm{~s} / \mathrm{d} 68$ tahun) dengan dominansi perempuan (55\%). Terdapat proporsi etiologi yang hampir sama antara penyakit jantung rematik dan kelainan degeneratif, dengan hanya 7 kasus yang disebabkan oleh endokarditis infektif. Sebagian besar
Tabel 2. Parameter ekokardiografi dalam penilaian hipertensi pulmoner

\begin{tabular}{llcc}
\hline & Pameter Ekokardiografi & $\mathrm{HP}$ & Tidak HP \\
\hline 1 & Evaluasi segera pasca operasi & $\mathrm{N}=23$ & $\mathrm{~N}=69$ \\
& a. TVG $(\mathrm{mmHg})$ & $38.6(15)$ & $22.7(7.4)$ \\
b. $\quad$ mPAP $(\mathrm{mmHg})$ & $32.3(6.5)$ & $17(5.9)$ \\
2 & Evaluasi saat follow up & $\mathrm{N}=20$ & $\mathrm{~N}=72$ \\
a. $\quad$ TVG $(\mathrm{mmHg})$ & $40.5(4)$ & $23.1(7.2)$ \\
b. $\quad$ mPAP & $31.7(5)$ & $18.1(7.5)$ \\
\hline
\end{tabular}

Data disajikan dalam rerata (simpang baku)

$\mathrm{TVG}=$ trikuspid valve gradient $=$ gradien trans trikuspid, $\mathrm{mPAP}=$ Mean pulmonary artery pressure $=$ tekanan rerata arteri pulmoner, $\mathrm{HP}=$ hipertensi pulmoner

Tabel 3.Analisis bivariat faktor-faktor yang berhubungan hipertensi pulmoner persisten ( $\mathrm{N}=92)$

\begin{tabular}{|c|c|c|c|c|c|}
\hline No & Variabel & & HP persisten & HP reversibel & $\mathrm{p}$ \\
\hline \multicolumn{6}{|c|}{ Karakteristik subjek } \\
\hline 1 & Usia (tahun)* & & $40(17-68)$ & $43(18-60)$ & 0.97 \\
\hline \multirow[t]{2}{*}{2} & Jenis Kelamin & Laki-laki & $9(22)$ & $32(78)$ & 1 \\
\hline & & Perempuan & $11(21.6)$ & $40(78.4)$ & \\
\hline \multirow[t]{3}{*}{3} & Etiologi & Rematik & $13(30.2)$ & $30(60.8)$ & \\
\hline & & Degeneratif & $5(11.9)$ & $37(88.1)$ & 0.11 \\
\hline & & Endokarditis infektif & $2(28.6)$ & $5(71.4)$ & \\
\hline \multirow[t]{2}{*}{4} & Jenis Kelainan & Regurgitasi & $16(22.9)$ & $54(77.1)$ & 0.77 \\
\hline & & Regurgitasi + stenosis & $4(18.2)$ & $18(81.8)$ & \\
\hline \multicolumn{6}{|c|}{ Parameter ekokardiografi pra operasi } \\
\hline 1 & Diameter atrium kiri (mm) & & $56.3(11.4)$ & $57.2(11.4)$ & 0.76 \\
\hline 2 & Fraksi ejeksi pra op (\%) & & $62.8(10.3)$ & $62.5(9.7)$ & 0.9 \\
\hline 3 & TAPSE $(\mathrm{cm})^{*}$ & & $1.6(1.0-2.2)$ & $2.0(1.2-3.3)$ & 0.01 \\
\hline 4 & $\operatorname{EDD}(\mathrm{mm})$ & & $60.2(7.0)$ & $60.9(7.3)$ & 0.71 \\
\hline 5 & $\operatorname{ESD}(\mathrm{mm})^{*}$ & & $38.5(29-57)$ & $39(26-73)$ & 0.86 \\
\hline 6 & Tekanan sistolik AP praop $(\mathrm{mmHg})^{*}$ & & $70(10-105)$ & $65(50-115)$ & 0.19 \\
\hline \multicolumn{6}{|c|}{ Parameter perioperatif dan segera pasca operasi } \\
\hline \multirow[t]{3}{*}{1} & Jenis operasi & Repair & $34(82.9)$ & $7(17.1)$ & 0.56 \\
\hline & & Replace-bioprothese & $15(71.4)$ & $6(28.6)$ & \\
\hline & & Replace-mekanik & $23(76.7)$ & $7(23.3)$ & \\
\hline \multirow{2}{*}{\multicolumn{2}{|c|}{ Obat HP perioperatif^ }} & $\mathrm{Ya}$ & $13(68.4)$ & $6(31.6)$ & 0.35 \\
\hline & & Tidak & $59(80.8)$ & $14(19.2)$ & \\
\hline \multirow[t]{2}{*}{3} & Fibrilasi atrium pasca op & Ya & $30(65.2)$ & $16(34.8)$ & 0.02 \\
\hline & & Tidak & $42(91.3)$ & $4(8.7)$ & \\
\hline \multirow[t]{2}{*}{4} & HP segera pasca operasi & Ya & $32(72.7)$ & $12(27.3)$ & 0.02 \\
\hline & & Tidak & $40(83.3)$ & $8(16.7)$ & \\
\hline 5 & AKM discharge $(\mathrm{cm} 2)^{*}$ & & $2.1(1.5-2.7)$ & $2.0(1.2-3.4)$ & 0.86 \\
\hline 6 & Rerata GTM discharge $(\mathrm{mmHg})^{*}$ & & $4.0(1.3)$ & $3.5(1.3)$ & 0.14 \\
\hline
\end{tabular}

Data kategorikal disajikan dalam $\mathrm{N}(\%)$, data numerik disajikan dalam rerata $(\mathrm{SB})$ atau median (min-max).

*Dianalisa denganuji Mann-Whitney, ` Dianalisa dengan uji Fisher

$\mathrm{HP}=$ Hipertensi pulmoner, $\mathrm{EDD}=$ end diastolic diameter, $\mathrm{ESD}=$ end systolic diameter, $\mathrm{TAPSE}=$ tricuspid annular plane systolic excursion, $\mathrm{AKM}=$ area katup mitral, $\mathrm{GTM}=$ gradien transmitral 
subjek menunjukkan irama dasar fibrilasi atrium (57.6\%). Terjadi pembesaran dimensi atrium kiri pada semua subjek penelitian dengan nilai rerata $57+11.4$ $\mathrm{mm}$. Rerata fungsi ventrikel kanan subjek secara umum masih baik. Semua subjek penelitian menggunakan vasodilator penghambat enzim konversi angiotensin, diuretik, dan digitalis/penyekat beta bila terdapat irama atrial fibrilasi sebelum operasi. Karakteristik dasar subjek penelitian dapat dilihat pada Tabel 1

Hampir setengah total subjek menjalani operasi repair katup mitral $(44.6 \%, \mathrm{~N}=41)$ dengan menggunakan ring annuloplasty. 21 subjek menjalani operasi pengantian katup bioprothese (22\%), dan 30 subjek menjalani operasi penggantian katup mekanik (32\%). Dari 80 subjek dengan regurgitasi trikuspid bermakna, 76 subjek dilakukan reparasi katup trikuspid. Obat vasodilator pulmoner hanya digunakan pada $20.7 \%(\mathrm{~N}=19)$ selama perioperatif.

Evaluasi hipertensi pulmoner dilakukan segera pasca operasi dan rerata follow up $11 \pm 5.5$ bulan. Hipertensi pulmoner didapatkan pada 23 subjek (25\%) segera pasca operasi dan pada 20 subjek $(20.7 \%)$ selama waktu follow up. Nilai gradien transtrikuspid dan tekanan rerata arteri pulmoner pada waktu segera pasca op dan evaluasi minimal 6 bulan dapat dilihat pada Tabel 5.3

Dari data karakteristik berdasarkan reversibilitas hipertensi pulmoner dalam pengamatan minimal 6 bulan, didapatkan data yang homogen untuk usia dan jenis kelamin di kedua kelompok. Dari analisis bivariat (Tabel 3.) terdapat hubungan yang bermakna antara etiologi kelainan katup dengan hipertensi pulmoner persisten. Adanya kombinasi regurgitasi dengan stenosis tidak mempengaruhi reversibilitas hipertensi pulmoner. Dari data ekokardiografi, didapatkan subjek dengan hipertensi pulmoner yang menetap mempunyai nilai TAPSE pra operatif yang lebih rendah dibandingkan dengan kelompok dengan hipertensi pulmoner reversibel (median 1.6 Vs 2.0, $\mathrm{p}=0.01$ ). Kelompok dengan hipertensi pulmoner persisten mempunyai tekanan sistolik pra operasi yang lebih tinggi dari kelompok dengan hipertensi pulmoner reversibel ( median $70 \mathrm{mmHg}$ Vs $65 \mathrm{mmHg}, \mathrm{p}=0.11$ )

Irama atrial fibrilasi pasca operasi mempunyai hubungan yang sangat bermakna dengan menetapnya hipertensi pulmoner $(p=0.02)$. Evaluasi rerata gradien transmitral segera pasca operasi menunjukkan nilai yang lebih tinggi pada pasien dengan hipertensi pulmoner persisten dibandingkan dengan yang reversibel ( $4.0 \mathrm{Vs} 3.5 \mathrm{mmHg}$ ). Dari analisis bivariat, didapatkan hubungan yang bermakna antara ada/ tidaknya hipertensi pulmoner segera pasca operasi dengan masih persitennya hipertensi pulmoner saat follow up $(\mathrm{p}=0.02)$.

Dari keseluruhan analisis bivariat diatas, didapatkan enam variabel yang bermakna dalam uji bivariat dengan $\mathrm{p}<0.25$, yakni etiologi regurgitasi mitral , nilai TAPSE pra operasi, tekanan sistolik arteri pulmoner pra operasi, irama fibrilasi atrium pasca operasi, nilai rerata gradien transmitral segera pasca operasi dan ada tidaknya hipertensi pulmoner segera pasca operasi. Dari analisis multivariat didapatkan bahwa nilai TAPSE pra operasi, irama atrial fibrilasi pasca operasi, dan nilai rerata gradien transmitral segera pasca operasi merupakan prediktor independen menetapnya hipertensi pulmoner pasca operasi koreksi katup mitral. (Tabel 4.) Irama

Tabel 4. Analisis multivariat faktor-faktor yang berhubungan dengan hipertensi pulmoner persisten

\begin{tabular}{|c|c|c|c|c|}
\hline $\mathrm{Nc}$ & Variabel independen & OR & IK $95 \%$ & $\mathrm{p}$ \\
\hline \multicolumn{5}{|c|}{ Step 1} \\
\hline 1 & Etiologi regurgitasi & 2.01 & $0.55-7.98$ & 0.27 \\
\hline 2 & Tekanan sistolik AP pra op & 1.02 & $0.98-1.06$ & 0.32 \\
\hline 3 & TAPSE pra op & 0.19 & 0.039-0.99 & 0.049 \\
\hline 4 & Atrial fibrilasi pasca op & 9.10 & $1.76-47.11$ & 0.008 \\
\hline 5 & Rerata GTM pasca op & 1.61 & $0.96-2.69$ & 0.069 \\
\hline 6 & HP segera pasca op & 0.89 & $0.26-3.09$ & 0.857 \\
\hline \multicolumn{5}{|c|}{ Step 4} \\
\hline 1 & TAPSE & 0.143 & $0.03-0.70$ & 0.017 \\
\hline 2 & Rerata GTM pasca op & 1.67 & $1.03-2.70$ & 0.038 \\
\hline 3 & EKG pasca operasi & 7.3 & $1.64-33.33$ & 0.009 \\
\hline
\end{tabular}

Hosmer-Lemeshow test $=0.073$, Kurva $\mathrm{ROC}=0.822$ 
fibrilasi yang dinilai pasca operasi meningkatkan risiko menetapnya hipertensi pulmoner dengan OR 7.3 [IK 95\% 1.64-33.33, $\mathrm{p}=0.009$ ], sedangkan peningkatan $1 \mathrm{mmHg}$ tekanan rerata gradient transmitral akan meningkatkan risiko hipertensi pulmoner persisten dengan OR 1.67 [IK 95\% 1.03-2.70, p=1.03-2.7, $\mathrm{p}=0.038$. Fungsi ventrikel kanan yang dinilai dengan TAPSE memberikan OR 0.143 [IK 95\% 0.03 $0.70, \mathrm{p}=0.017]$ terhadap risiko hipertensi pulmoner persisten.

\section{Diskusi}

Studi ini menilai perjalanan hipertensi pulmoner pada subjek dengan hipertensi pulmoner berat yang akan menjalani operasi koreksi katup mitral. Selama periode penelitian, didapatkan 92 subjek yang layak untuk dilakukan analisa statistik. Terdapat 47 subjek yang dikeluarkan dari sampel penelitian oleh karena adanya komorbid, terdapat disfungsi katup bermakna, meninggal perioperatif atau selama waktu follow up, dan data parameter evaluasi yang tidak lengkap.

Pada penelitian ini, rentang usia subjek cukup jauh, dengan usia termuda 17 tahun, dan usia tertua 68 tahun (median 40 tahun). Hal ini tampaknya disebabkan oleh perbedaan etiologi yang mendasari penyakit regurgitasi memiliki predileksi usia yang berbeda juga. Pasien dengan kelainan rematik memiliki predileksi usia yang lebih muda, sedangkan pasien dengan kelainan degeneratif biasanya mengenai pasien dengan usia yang lebih dewasa. Hal ini dapat dilihat pada studi yang dilakukan oleh Tempe dkk yang menilai pasien-pasien operasi katup yang disebabkan oleh penyakit jantung rematik didapatkan usia subjek yang relatif muda, dengan nilai rerata 27 dan 30 tahun $^{11}$, kebalikannya, pada penelitian oleh Barbieri $\mathrm{dkk}^{12}$ yang mengambil studi dari subregistri regurgitasi mitral akibat kelaian flail katup mital, atau oleh Goldstone $\mathrm{dkk}^{13}$ yang hanya mengkhususkan subjek penelitiannya pada pasien regurgitasi mitral akibat degeneratif, memiliki rerata usia subjek yang jauh lebih tua, dengan rerata pada kedua studi \pm 60 tahun.

Dari hasil penelitian ini dapat terlihat bahwa residual hipertensi pulmoner segera pasca operasi masih ditemui pada 23 (25\%) dari seluruh subjek penelitian. Tidak terdapat penurunan yang terlalu jauh jika dibandingkan dengan setelah follow up dengan rerata $11 \pm 5.5$ bulan, dimana didapatkan hipertensi pulmoner persisten masih ada pada 20 kasus
(20.7\%). Prevalensi residual hipertensi pulmoner baik segera maupun dalam follow up jangka panjang sangat bervariasi antar studi dengan studi lainnya. Evaluasi segera pasca operasi yang sudah dipublikasi mendapati residual hipertensi pulmoner bervariasi antara $10-46 \%^{12-14}$ sedangkan studi-studi yang melakukan evaluasi jangka panjang mendapatkan prevalensi 33-64\%. ${ }^{14-16} \mathrm{Hal}$ ini mungkin disebabkan oleh sangat bervariasinya karakteristisk subjek yang diteliti, modalitas untuk menilai ada tidaknya hipertensi pulmoner, dan lamawaktu evaluasi. Namun belum ada studi yang melihat perjalanan hipertensi pulmoner pasca operasi regurgitasi dalam dalam jangka waktu tertentu. Secara teoritis penurunan tekanan pulmoner masih diharapkan dalam hitungan waktu-bulan setelah operasi koreksi ${ }^{1}$, namun dalam studi ini nampaknya evaluasi hipertensi pulmoner dalam jangka waktu pengamatan rerata $11 \pm 5.5$ bulan, didapatkan penurunan yang tidak besar, dari 25\% menjadi $20.7 \%$. Studi oleh Zielinski dkk yang melihat efek perubahan hemodinamik pulmoner saat sebelum operasi, 6 dan 12 bulan pasca operasi penggantian katup mitral dengan kelainan anatomis dominan stenosis mitral. Dalam studinya, didapatkan perubahan hemodinamik paru yang bermakna antara sebelum dan 6 bulan pasca operasi, namun hanya terdapat penurunan yang tidak bermakna terhadap tekanan sistolik arteri pulmoner, tekanan baji kapiler pulmoner dan resistensi vaskular pulmoner antara 6 bulan dengan 12 bulan pasca operasi. ${ }^{17}$

Hasil analisis multivariate pada studi ini mendapatkan faktor risiko independen terhadap hipertensi pulmoner persisten pasca operasi katup mitral adalah nilai TAPSE, ada tidaknya atrial fibrilasi pasca operasi, dan nilai rerata gradien transmitral segera pasca operasi. Penilaian fungsi ventrikel kanan dengan TAPSE direkomendasikan sebagai indikator prognostik pada pasien dengan hipertensi pulmoner untuk menilai beratnya penyakit dan menilai respon pengobatan, hal ini disebabkan terutama karena pemeriksaan dengan TAPSE dapat dilakukan hampir pada semua pasien dan merupakan pemeriksaan yang relatif mudah dilakukan dengan fasilitas sederhana. Ghio dan Forfia, dalam studinya menyimpulkan bahwa menurunnya nilai TAPSE (masing-masing menggunakan titik potong 15 dan $18 \mathrm{~mm}$ ) berhubungan dengan beratnya hipertensi pulmoner yang terjadi dan berhubungan dengan kesintasan 1 dan 2 tahun. ${ }^{18.19}$ Namun sampai saat ini belum ada studi yang memasukkan fungsi ventrikel kanan sebagai variabel dalam mencari faktor- 
faktor yang berhubungan dengan hipertensi pulmoner persisten pasca operasi katup mitral. Dari penelitian ini didapatkan subjek dengan hipertensi pulmoner persisten memiliki TAPSE yang lebih rendah dibandingkan dengan subjek dengan hipertensi pulmoner reversibel (1.6 Vs $2.1 \mathrm{~cm}, \mathrm{p}=0.01)$. dari analisis multivariat didapatkan OR 0.143 (IK 95\% 0.03-0.70, p=0.017), dimana dapat dinterpretasikan dengan $10 \mathrm{~mm}$ penurunan nilai TAPSE akan meningkatkan 1/0.143 = 6.9 kali risiko hipertensi pulmoner persisten.

Studi ini mendapatkan irama atrial fibrilasi pasca operasi merupakan faktor risiko independen terhadap hipertensi pulmoner persisten dengan risiko peningkatan sebesar 7.3 kali (IK 95\% 1.6333.33, $\mathrm{p}=0.09$ ). Hal ini serupa dengan studi yang dilakukan oleh Kabucku, dkk yang mendapatkan bahwa konversi irama fibrilasi atrium menjadi irama sinus secara bermakna menurunkan kelas fungsional dan tekanan rerata arteri pulmoner. Dalam studinya konversi menjadi sinus dilakukan baik dengan kardioversi maupun dengan medikamentosa. ${ }^{20} \mathrm{Hal}$ ini diterangkan lebih jelas dalam studi yang dilakukan oleh Rottalaender yang melakukan subgroup analisis pada pasien dengan hipertensi pulmoner dan kelainan jantung kiri. Pada penelitiannya didapatkan pasien dengan atrial fibrilasi mempunyai ukuran atrium kiri yang lebih besar dan TAPSE yang lebih rendah, serta mempunyai nilai tekanan baji kapiler pulmoner yang lebih tinggi. Pada pemeriksaan invasif didapatkan subjek dengan atrial fibrilasi mempunyai nilai tekanan sistolik dan rerata arteri pulmoner yang lebih tinggi dibandingkan dengan irama sinus. ${ }^{21}$

Terdapat dua studi yang menghubungkan antara peningkatan gradien transmitral dengan hipertensi pulmoner persisten, namun keduanya menghubungkan peningkatan gradien tersebut dengan adanya mismatch pasien-katup. Lam, dkk melakukan evaluasi ekokardiografi dalam rentang waktu $5 \pm 4.1$ tahun pada pasien yang menjalani operasi penggantian katup mitral. Dalam studinya, hipertensi post operatif dihubungkan dengan ukuran katup mitral yang lebih kecil, peningkatan gradien mitral, fraksi ejeksi yang lebih rendah dan irama fibrilasi atrium. ${ }^{15}$ Sedangkan Li dkk pada publikasinya tahun 2005 yang membuat hipotesa bahwa mismatch pasien-katup berkorelasi bermakna dengan tekanan sistolik arteri pulmoner pasca operasi, dan hal ini berhubungan dengan lebih tingginya gradien transmitral pada subjek tersebut. ${ }^{16}$ Pada studi ini tidak dilakukan analisa ada tidaknya mismatch pasien-katup, namun rerata gradien transmitral segera pasca op berhubungan bermakna dengan timbulnya hipertensi pulmoner persisten, dengan OR 1,67 (IK 95\% 1.032.7, $\mathrm{p}=0.038$ ). Walaupun demikian, jika dievaluasi secara klinis, perbedaan rerata gradien transmitral antara kelompok dengan hipertensi pulmonal persisten dan yang reversibel hanya berbeda $0.5 \mathrm{mmHg}(4 \mathrm{mmHg}$ Vs 3,5 mmHg), yang mungkin tidak akan memberikan makna klinis yang bermakna.

Dari data parameter ekokardiografi saat follow $u p$, didapatkan dimensi ventrikel kiri yang mengecil jika dibandingkan dengan nilainya saat pra operasi, terutama pada nilai dimensi diastolik akhir ventrikel kiri. Hal ini berhubungan dengan menurunnya volume diastolik akhir ventrikel kiri yang dapat diprediksi karena faktor volum regurgitasi yang hilang setelah dilakukan operasi koreksi. ${ }^{22}$ Jika dibandingkan antara grup dengan hipertensi pulmoner persisten dengan grup dengan hipertensi pulmoner yang reversibel, nampaknya pada grup dengan hipertensi pulmonal reversibel memiliki dimensi diastolik akhir yang secara bermakna lebih kecil dari grup dengan hipertensi pulmonal persisten [50.9(7.5) Vs 55.9 (7.7), $\mathrm{p}=0.031$ ]. Sampai sejauh ini, belum ada satu studi pun yang menilai efek perubahan dimensi ventrikel atau terjadinya reverse remodeling pasca operasi dengan menetapnya hipertensi pulmonal setelah operasi koreksi. Evaluasi fungsi ventrikel kanan pada saat follow up memberikan hasil yang konsisten terhadap ada tidaknya hipertensi pulmonal. Subjek dengan hipertensi pulmonal persisten nampaknya memiliki nilai TAPSE yang bermakna lebih rendah dari grup dengan hipertensi pulmonal reversibel.

\section{Keterbatasan Penelitian}

Data yang diambil pada studi ini merupakan data sekunder yang diambil secara retrospektif dari rekaman medis atau arsip divisi noninvasif PJNHK. Penelitian ini juga tidak menilai komplikasi perioperatif dan obatobatan yang digunakan pasca operasi yang mungkin dapat berpengaruh terhadap perubahan hipertensi pulmoner pasca operasi.

\section{Kesimpulan}

Hipertensi pulmoner persisten pasca operasi koreksi katup mitral pada pasien dengan regurgitasi mitral organik terjadi pada pada $20.7 \%$ pasien dalam evaluasi 
Jurnal Kardiologi Indonesia

dengan rerata $11 \pm 5.5$ bulan.Nilai TAPSE pra operasi, irama atrial fibrilasi pasca operasi, dan nilai rerata gradien transmitral pasca operasi merupakan faktor risiko independen terhadap timbulnya hipertensi pulmoner persisten pasca operasi koreksi katup mitral.

\section{Daftar Pustaka}

1. Vahanian A, Baumgartner H, Bax J, Butchart E, Dion R, Filippatos $\mathrm{G}$, et al. Guidelines on the management of valvular heart disease: The Task Force on the Management of Valvular Heart Disease of the European Society of Cardiology. Eur Heart J. 2007; 28(2): 230-68.

2. Nkomo VT, Gardin JM, Skelton TN, Gottdiener JS, Scott CG, Enriquez-Sarano M. Burden of valvular heart diseases: a population-based study. Lancet. 2006; 368(9540): 1005-11.

3. Bonow RO, Carabello BA, Chatterjee K, de Leon AC, Jr., Faxon DP, Freed MD, et al. 2008 Focused update incorporated into the ACC/AHA 2006 guidelines for the management of patients with valvular heart disease: a report of the American College of Cardiology/American Heart Association Task Force on Practice Guidelines (Writing Committee to Revise the 1998 Guidelines for the Management of Patients With Valvular Heart Disease): endorsed by the Society of Cardiovascular Anesthesiologists, Society for Cardiovascular Angiography and Interventions, and Society of Thoracic Surgeons. Circulation. 2008; 118(15): e523-661.

4. Thenappan T, Shah SJ, Rich S, Tian L, Archer SL, GombergMaitland M. Survival in pulmonary arterial hypertension: a reappraisal of the NIH risk stratification equation. Eur Respir J. 2010; 35(5): 1079-87.

5. Galie N, Hoeper MM, Humbert M, Torbicki A, Vachiery JL, Barbera JA, et al. Guidelines for the diagnosis and treatment of pulmonary hypertension: The Task Force for the Diagnosis and Treatment of Pulmonary Hypertension of the European Society of Cardiology (ESC) and the European Respiratory Society (ERS), endorsed by the International Society of Heart and Lung Transplantation (ISHLT). Eur Heart J. 2009; 30(20): 2493-537.

6. McLaughlin VV, Archer SL, Badesch DB, Barst RJ, Farber HW, Lindner JR, et al. ACCF/AHA 2009 expert consensus document on pulmonary hypertension: a report of the American College of Cardiology Foundation Task Force on Expert Consensus Documents and the American Heart Association: developed in collaboration with the American College of Chest Physicians, American Thoracic Society, Inc., and the Pulmonary Hypertension Association. Circulation. 2009; 119(16): 2250-94.

7. Mubeen M, Singh AK, Agarwal SK, Pillai J, Kapoor S, Srivastava AK. Mitral valve replacement in severe pulmonary arterial hypertension. Asian Cardiovasc Thorac Ann. 2008; 16(1): 3742.

8. Haddad F, Kudelko K, Mercier O, Vrtovec B, Zamanian RT, de Jesus Perez V. Pulmonary hypertension associated with left heart disease: characteristics, emerging concepts, and treatment strategies. Prog Cardiovasc Dis. 2011; 54(2): 154-67.

9. Porter TR, Taylor DO, Cycan A, Fields J, Bagley CW, Pandian NG, et al. Endothelium-dependent pulmonary artery responses in chronic heart failure: influence of pulmonary hypertension. J Am Coll Cardiol. 1993; 22(5): 1418-24.

10. Deuchar GA, Docherty A, MacLean MR, Hicks MN. Pulmonary hypertension secondary to left ventricular dysfunction: the role of nitric oxide and endothelin-1 in the control of pulmonary vascular tone. Br J Pharmacol. 2002; 135(4): 1060-8.

11. Tempe DK, Hasija S, Datt V, Tomar AS, Virmani S, Banerjee A, et al. Evaluation and Comparison of Early Hemodynamic Changes After Elective Mitral Valve Replacement in Patients With Severe and Mild Pulmonary Arterial Hypertension. J Cardiothorac Vasc Anesth. 2009; 23(3): 298-305

12. Barbieri A, Bursi F, Grigioni F, Tribouilloy C, Avierinos JF, Michelena HI, et al. Prognostic and therapeutic implications of pulmonary hypertension complicating degenerative mitral regurgitation due to flail leaflet: A Multicenter Long-term International Study. Eur Heart J. 2011; 32: 751-9

13. Goldstone AB, Chikwe J, Pinney SP, Anyanwu AC, Funt SA, Polanco A, et al. Incidence, Epidemiology, and Prognosis of Residual Pulmonary Hypertension After Mitral Valve Repair for Degenerative Mitral Regurgitation. Am J Cardiol 2011; 107: 755-60.

14. Walls MC, Cimino N, Bolling SF, Bach DS. Persistent pulmonary hypertension after mitral valve surgery: does surgical procedure affect outcome? J Heart Valve Dis. 2008; 17(1): $1-9$.

15. Lam BK, Chan V, Hendry P, Ruel M, Masters R, Bedard P, et al. The impact of patient-prosthesis mismatch on late outcomes after mitral valve replacement. J Thorac Cardiovasc Surg. 2007; 133(6): 1464-73.

16. Li M, Dumesnil JG, Mathieu P, Pibarot P. Impact of valve prosthesis-patient mismatch on pulmonary arterial pressure after mitral valve replacement. J Am Coll Cardiol. 2005; 45(7): 1034-40.

17. Zielinski T, Pogorzelska H, Rajecka A, Biedermavn A, Sliwinski M, Korewicki J. Pulmonary hemodynamics at rest and effort, 6 and 12 months after mitral valve replacement: a slow regression of effort pulmonary hypertension. Int J Cardiol. 1993; 42(1): 57-62.

18. Ghio S, Klersy C, Magrini G, D’Armini AM, Scelsi L, Raineri $\mathrm{C}$, et al. Prognostic relevance of the echocardiographic assessment of right ventricular function in patients with idiopathic pulmonary arterial hypertension. Int J Cardiol. 2010; 140(3): 
Ariani R dkk: Prediktor hipertensi pulmonal persisten pasca koreksi mitral regurgitasi

$272-8$.

19. Forfia PR, Fisher MR, Mathai SC, Housten-Harris T, Hemnes AR, Borlaug BA, et al. Tricuspid annular displacement predicts survival in pulmonary hypertension. Am J Respir Crit Care Med. 2006; 174(9): 1034-41.

20. Kabukcu M, Yanik E, Demircioglu F, Gölbasi I, Ersel F. Effects of Late Regain of Sinus Rhythm on Pulmonary Artery Pressure and Functional Status in Patients with Mitral Valve Replacement Surgery and Atrial Fibrillation. J Heart Valve Dis. 2004;
13: 937-41.

21. Rottlaender D, Motloch LJ, Schmidt D, Reda S, Larbig R, Wolny $\mathrm{M}$, et al. Clinical impact of atrial fibrillation in patients with pulmonary hypertension. PLoS One. 2012; 7(3): e33902.

22. Hung L, Rahimtoola SH. Reverse remodeling after heart valve replacement and repair. In: Greenberg B, editor. Cardiac remodeling mechanisms and treatment. New York: Taylor \& Francis; 2006. p. 417-40. 